\title{
Prevention or cure in times of crisis: the case of screening for colorectal cancer
}

\author{
Fernando Carballo ${ }^{1}$ and Miguel Muñoz-Navas² \\ ${ }^{1}$ Department of Gastroenterology. School of Medicine. University of Murcia. Service of Gastroenterology. Hospital \\ Universitario Virgen de la Arrixaca. Murcian Biosanitary Research Institute. Murcia, Spain. ${ }^{2}$ Department of \\ Gastroenterology. School of Medicine. University of Navarra. Pamplona, Spain. Service of Gastroenterology. Clínica \\ Universidad de Navarra. Pamplona, Spain
}

\begin{abstract}
Colorectal cancer is a serious health problem in which screening is capable of reducing both the mortality and the incidence of the disorder. Colonoscopy, the mainstay of this type of screening, allows to establish an early diagnosis and also to eliminate malignant precursor lesions. The screening test which is performed in Spanish programs is the determination of fecal occult blood using the immunochemical method which gives around $70 \%$ of positive values for colonoscopy for any type of neoplasia. As a result, in 2009 the National Health System set as an objective that these programs cover $50 \%$ of the population by 2015 . It is well known that colon screening is highly cost effective with a ratio of around $2500 \Leftrightarrow$ per QALY, much lower than ratios of other programs. Only the direct costs of colon and rectal cancer in Spain can be estimated at more than one thousand million euros per year. Early diagnosis and the cancers avoided thanks to screening can reduce these costs by $40 \%$. The impact that the introduction of this screening has on health services can be lessened if the indications for colonoscopy are followed adequately. In conclusion, there is no justification for not acting to prevent CRC and this is especially so in times of crisis as there is no better social cost invested than that which saves suffering, deaths and even money.
\end{abstract}

Key words: Prevention of colorectal cancer. Cost effectiveness.

Carballo F, Muñoz-Navas M. Prevention or cure in times of crisis: the case of screening for colorectal cancer. Rev Esp Enferm Dig 2012;104:537-545.

Received: 20-09-2012

Accepted: $31-10-2012$

Correspondence: Fernando Carballo. Service of Gastroenterology. Hospital Universitario Virgen de la Arrixaca. Ctra. Madrid-Cartagena, s/n. El Palmar. Murcia, Spain.

e-mail: luisf.carballo@carm.es

\section{ABBREVIATIONS}

AEG: Spanish Association of Gastroenterology. AECC: Spanish Association Against Cancer.

APCC: Alliance for the Prevention of Colon Cancer. CRC: colorectal cancer.

CSPN: Cancer Screening Program Network.

DNA: deoxyribonucleic acid.

FIT: fecal immunochemical testing.

FOBT: fecal occult blood test.

gFOBT: stool guaiac test for fecal occult blood.

ICER: incremental cost effectiveness ratio.

NNE: number needed to examine.

NHS: National Health Systems.

NNS: number needed to screen.

NPS: National Polyp Study.

QALY: quality-adjusted life year.

RCT: randomized clinical trial.

RPI: Retail Price Index.

SEE: Spanish Society of Epidemiology.

SEED: Spanish Society of Digestive Endoscopy. semFYC: Society of Family and Community Medicine. SEOM: Spanish Society of Medical Oncology.

SEOR: Spanish Society of Radiotherapeutic Oncology. SEPD: Spanish Society of Digestive Pathology.

USA: Unites States of America.

WHO: World Health Organization.

\section{COLORECTAL CANCER (CRC) SCREENING IS EFFICIENT IN REDUCING THE MORTALITY AND INCIDENCE OF THE DISEASE}

CRC is the most frequent cancer in Spain with 28, 551 new cases in 2008 (1). In 2010, it was the sixth cause of death with 14,833 people, double the number of deaths from breast cancer and six times that of traffic accidents (2). Unlike other countries, such as the United States of 
America (USA) where screening is more widespread, in Spain there is a tendency for the incidence of CRC in both sexes and also mortality, especially in males, to be rising $(1,3)$. These trends have been analyzed in detail by Spanish groups both for the country as a whole (4) and for the Autonomous Region of Andalucía in particular (5).

The best hope for reversing this situation is primary prevention and especially widespread screening of the population. The 2009 report on the situation of cancer in the USA (7) shows a $26 \%$ reduction in mortality from CRC over the period 1975-2000 and estimates that of this $26 \%$ only $3 \%$ is attributable to treatment, in spite of the advances made, while control of risk factors accounts for $9 \%$ and screening for the remaining $14 \%$. In other words, the reduction in CRC mortality in the USA can be justified in up to $88.5 \%$ of cases by prevention, and screening alone is responsible for more than half of this reduction (54\%). The authors claim that by maintaining these trends, CRC mortality could be reduced by $36 \%$ in the USA by 2020 , and even by $50 \%$ if the prevention programs are intensified.

Although no doubts exist regarding the importance of establishing widespread screening programs, there is considerable discussion regarding the test to be used, the profile of the programs to be developed and, of course, their cost effectiveness and sustainability.

\section{ALTERNATIVES TO CRC SCREENING}

There is no CRC screening without colonoscopy although this may not be the initial examination. The effect of colonoscopy is double, as it combines the ability to make a diagnosis with the direct treatment of malignant precursor lesions (adenomas) and even non-invasive carcinomas with a good prognosis. Since 1993 the effects of the endoscopic elimination of adenomas on the incidence of CRC has been well known thanks to the results of the National Polyp Study (NPS). These range from 76 to $90 \%$ depending on the cohort studied (8). Similarly, a recent and extensive population-based case-control study carried out in Germany concluded that colonoscopy reduces the risk of CRC by $77 \%$ (9) and another study in Canada by $48 \%$ (10). As for CRC mortality in the USA, the reduction attributable to colonoscopies has been estimated at between $13 \%$ and $19 \%$ (11) and in Canada at $81 \%$ in relative terms (10). In Ontario (Canada), in a study involving more than two million people it was observed that for each $1 \%$ increase in colonoscopies there was a $3 \%$ reduction in the mortality rates from CRC (12). In the USA it has been estimated that the percentage of deaths from CRC attributable to the non-use of colonoscopies ranges from 38 to $44 \%$, deaths, which would have been avoided if in the preceding 10 years the population eligible to take part in a CRC screening program with colonoscopy had been included (11). The same NPS group has demonstrated that the direct effect of polypectomy on CRC mortality is $53 \%$ in the long term (13). Two other recent Canadian studies report an association between colonoscopy and reductions in CRC mortality, although this is attributable only to distal cancers $(14,15)$.

Bearing in mind different healthcare models and different perspectives, many countries, such as the USA, Germany or Poland develop their screening programs based on direct colonoscopy $(16,17)$ and in general following opportunistic criteria. Others, including our own, with established National Health Systems (NHS) opt for performing initial tests, which if found positive then lead to colonoscopy. The reason is to optimize colonoscopy by improving the post-test chances of finding lesions. But opting for a non-opportunistic model does not mean that opportunistic screening does not co-exist with public programs. Consequently, in such cases, it is very important to record the opportunistic screening that takes place outside the NHS, to take the results into account and guarantee its quality.

Fecal occult blood test (FOBT) is the screening test with the best evidence base. Four large randomized clinical trials (RCT) have analyzed screening using the detection of fecal occult blood by the stool guaiac test for fecal occult blood (gFOBT) including 327,043 participants in Denmark (Funen) (18), Sweden (Goteborg) (19), USA (Minnesota) (2) and the United Kingdom (Nottingham) (21). A Cochrane review estimates that for these four RCTs an overall $16 \%$ reduction in mortality $(\mathrm{RR}=0.84 ; 95 \% \mathrm{CI}=0.78-0.90)$ (22). Furthermore, follow-up of the Minnesota cohort has demonstrated a significant reduction in the incidence of CRC $-17 \%$ in the biannual FOBT arm and $20 \%$ in the annual FOBT arm (23). Following these emblematic RCTs, other large controlled but not randomized studies have shown the same benefit in terms of reduction of mortality (24).

The gFOBT is currently being superseded by fecal immunochemical testing (FIT) first developed in Japan in the 1980s and which was first used in European programs in the 90s (25). One advantage over the chemical method is that it only detects human hemoglobin and thus does not require a diet. More importantly, it is capable of detecting more significant neoplasia, especially high-risk adenomas $(26,27)$.

In February 2012 the first results from the important Spanish ColonPrev study were published, they reinforce the hypothesis that the most appropriate option is to use a screening strategy based on FIT, followed by colonoscopy in positive cases. This study is a large RCT comparing for the first time FIT every two years with direct colonoscopy performed only once. The hypothesis is the non-inferiority of FIT and the main variable was 10-year mortality. More than 50,000 subjects were invited to participate and the first round in the FIT arm has been completed and all the endoscopic explorations via colonoscopy. The observed rate of detection of cancers and adenomas after the first round indicates that FIT detects the same number of cancers as colonoscopy although a greater number of adenomas are detected by the latter procedure (28).

Flexible sigmoidoscopy has also been shown to be effective in reducing the mortality and incidence as a screening test in three large RCTs. The UK Flexible Sigmoidoscopy 
Screening Trial reported in 2010 , in the analysis by intention to treat, significant reductions in incidence and mortality of 23 and $31 \%$ respectively which rose to 33 and $43 \%$ in the analysis by protocol (29). In 2011 the results of the Italian SCORE Trial were published showing significant reductions in incidence by intention to treat of $18 \%$, while in the same type of analysis the reduction in mortality was $22 \%$ although this was not statistically significant. In the analysis by protocol both incidence and mortality decreased significantly by 31 and 38\% (30). In 2012 the PLCO Cancer Screening Trial reported for sigmoidoscopy a $50 \%$ reduction in distal CRC while mortality for proximal CRC was unchanged (31), a finding also observed in the UK Flexible Sigmoidoscopy Screening Trial (29).

The use of sigmoidoscopy as a screening test for CRC assumes that it is unlikely that subjects will have lesions in the right colon if they have none in the left colon. This assumption is incorrect as we showed some years ago in a population at standard risk (32) and although it may seem partially valid for pedunculated adenomas this is not at all the case for flat lesions and serrated adenomas, which may explain the observed lack of effect on the reduction of mortality in cancer of the right colon in some studies $(33,34)$. To date there are no other screening tests which have proved to be effective in reducing mortality and incidence although good results have been obtained in their ability to detect lesions.

Among the more widespread alternative imaging techniques is CT colonography. This has been used as a screening tool most extensively in the USA. It shows good sensitivity and specificity to detect polypoidal lesion larger than $10 \mathrm{~mm}$ but not for flat lesions or polyps smaller than $5 \mathrm{~mm}(35)$.

Colon capsule endoscopy is an emerging imaging technique which has also shown promising results regarding its ability to detect lesions $(36,37)$ and which could be used in the future for CRC screening in patients with standard risks and in those patients refusing to undergo conventional colonoscopy or in those in whom colonoscopy does not allow visualization of all the colon (38). From the perspective of population screening, the greatest disadvantage of both tests is the additional cost.

Among the fecal tests which represent alternatives to FOBT much work is currently focusing on the identification of increasingly better fecal DNA markers, but for the moment such tests are not real alternatives for use in mass screening (39).

\section{CRC SCREENING IN SPAIN}

At the end of 2009, a key event occurred when the update of the National Cancer Strategy of the NHS (40), as part of its objective 10 dedicated to the early detection of $\mathrm{CRC}$, established the mandate of introducing population screening programs for CRC for medium to low risk populations aged between 50 and 69 years old with biannual
FOBT as the screening test. Furthermore, a national coverage of $50 \%$ was established for 2015. Significantly, the decision was taken to set up information systems allowing evaluation at the national and regional levels, adopting the quality standards of the European guidelines (41) and assigning this evaluation to the Spanish Cancer Screening Network (42).

In Spain there exists a thriving and active populationbased screening of high quality. This is the case thanks to the pioneering programs carried out in Cataluña from 2000, Valencia from 2005 and Murcia from 2006 as well as those appearing afterwards. These programs were promoted by institutions with an in-depth knowledge of the requirements and methodology necessary to set up and run this type of programs. These institutions are integrated in the pre-existing Cancer Screening Program Network (CSPN). The CSPN is formed by the people in charge of cancer screening programs in the Autonomous regions, who are experts in Public Health, its main objective is the exchange of experiences between managers of population-based programs of early cancer detection. It is in this aim that they organize the CSPN annual meeting, as an opportunity for members to meet (42). In 2007 the majority of the members of the network participated, along with specialists in digestive disorders, pathologists, radiologists, surgeons, primary care physicians and oncologists in a special meeting dedicated to establishing the necessary recommendations for the planning and setting up of demographically-based organized programs for the prevention of CRC (43).

The interest of Spanish gastroenterologists in screening for CRC began in the 1980s (44-49). In 1999 the Gastrointestinal Oncology Group of the Spanish Association of Gastroenterology (AEG) began the multicenter studies Epicolon I and Epicolon II which have been supplying high impact information on family and hereditary forms of CRC in Spain (50). In 2004 the AEG, together with the Society of Family and Community Medicine (semFYC) and the Iberoamerican Cochrane Center published the relevant Practical Clinical Guidelines for the Prevention of Colorectal Cancer, which was updated in 2009 (51,52) and which until the recent appearance of the European Guidelines (41) were the main source used by Spanish screening programs especially regarding decisions on follow-up. In 2006 the group and the institutional screening programs began a steady collaboration which over the course of 2007 was articulated around the ColonPrev studied described above. A recent additional benefit of the participation of Spanish specialist in digestive disorders has been the publication of Practical Clinical Guidelines on the Quality of Colonoscopy for Colorectal Screening, promoted conjointly by the AEG and the Spanish Society of Digestive Endoscopy (SEED) $(53,54)$.

Also in 2007 the gestation of the Alliance for the Prevention of Colon Cancer (APCC) began in Spain, as an initial idea of the Spanish Association Against Cancer (AECC), the AEG, the semFYC and the Spanish Society of Medical Oncology (SEOM). It was formally established 
Table I. Detection rates obtained in the Colorectal Cancer Prevention Program in the region of Murcia between the years 2006 and 2010

\begin{tabular}{ll}
\hline Lesions detected & Total \\
\hline Number of persons with appropriate test & 47,088 \\
Number of persons with a positive test & 5,009 \\
Number of colonoscopies performed & 4,708 \\
Number of persons with high risk adenomas* & 1,813 \\
Number of persons with low risk adenomas & 1,295 \\
Number of persons with any adenoma & 3,108 \\
Number of persons with invasive cancer detected & 161 \\
Number of persons with high adenoma or invasive & \\
cancer detected & 1,974 \\
Number of persons with any adenoma and invasive & \\
cancer detected & 3,269
\end{tabular}

Rate of persons with high risk adenomas*

$\mathrm{N} .^{\circ}$ of persons with high risk adenomas/Number of person with appropriate test $\times 1,000$

Rate of persons with low risk adenomas

$\mathrm{N} .^{\circ}$ of persons with low risk adenomas/ Number of person with appropriate test $\times 1,000$

Rate of persons with any adenoma

$\mathrm{N} .{ }^{\circ}$ of persons with any adenoma/Number of person with appropriate test $x 1,000$

Rate of persons with invasive cancer detected

$\mathrm{N} .^{\circ}$ of persons with invasive cancer detected/Number of person with appropriate test $\times 1,000$

Rate of persons with high risk adenoma and

invasive cancer detected

Number of persons with high risk adenoma and

invasive cancer detected/Number of person with

appropriate test $\times 1,000$

Rate of persons with any adenoma and invasive

cancer detected

Number of persons with any adenoma and invasive cancer detected/Number of person with appropriate test $\times 1,000$

* Persons with 3 or more adenomas and/or some of them equal or greater than 10 $\mathrm{mm}$, or with a villous component or high grade dysplasia (includes the previously termed carcinoma in situ and intramucosal carcinoma).

in 2008 with the incorporation at its foundation of a patient association, Europacolon, the Spanish Society of Epidemiology (SEE) and the Spanish Society of Radiotherapeutic Oncology (SEOR). Currently the APCC is made up of 15 different scientific societies, among them the Spanish Society of Digestive Pathology (SEPD) and the SEED. For further information on this Alliance we direct readers to the excellent article by Morillas et al. (55).

As was pointed out above, the first autonomous region to begin an institutional screening program was Cataluña in 2000. This initiative was joined over the years 20052006 by the regions of Valencia and Murcia and in 20082009 by the Basque Country, Cantabria and the Canary Islands. In 2010 La Rioja also began to participate. Furthermore, Aragón and Castilla-León are currently devel-
Table II. Tumor stages of the invasive cancers detected in the Colorectal Cancer Prevention Program in the region of Murcia between the years 2006 and 2010

\begin{tabular}{ll}
\hline Tumors detected. Stage & Total \\
\hline Number of persons with invasive cancer detected & 161 \\
Number of cancers in stage I & 78 \\
Number of cancers in stage II & 31 \\
Number of cancers in stage III & 37 \\
Number of cancers in stage IV & 14 \\
Number of cancers in unknown stage & 1
\end{tabular}

Percentage of cancers in stage I

Number of cancers detected in stage I/Number of cancers detected in stage I, II, III or IV x 100

Percentage of cancers in stage II

Number of cancers detected in stage II/Number of cancers detected in stage I, II, III or IV x 100

Percentage of cancers in stage III

Number of cancers detected in stage III/Number of cancers detected in stage I, II, III or IV x 100

Percentage of cancers in stage $\mathrm{IV}$

Number of cancers detected in stage IV/Number of cancers detected in stage I, II, III or IV x 100

oping pilot programs. Other autonomous regions have announced the prompt commencement of their programs. The data available in 2012, which are changing and only suggestive, show that the coverage of these programs in the Spanish state for the population aged 50-69 years is $14.26 \%(1,466,380$ people included from an official national census of $10,283,772$ people in this age range) (56). The highest relative coverage is in Cantabria (69\%), followed by the Basque Country (51\%). All the autonomous regions currently use FIT as the screening test (57).

There is a high level of consistency obtained from the different screening programs with regard to the results of the detection rates of cancer and adenomas. As an example, we present in tables the as yet unpublished results for the program in Murcia. The detection rates are shown in table I, while table II describes the stages of the invasive cancers detected and table III the positive predictive values. Finally in table IV we list the Numbers Needed to Screen (NNS) and the Numbers Needed to Examine (NNE) with colonoscopy. From the analysis of these tables it can be deduced that screening colonoscopy, after positive FIT, is highly effective as it detects some type of neoplasia in about $70 \%$ of subjects examined, of whom more than $40 \%$ have significant neoplasia (subjects with high risk adenomas or invasive cancer) (Table III). The NNS to detect an invasive cancer is 293 (292.47), falling to 24 (23.85) for significant neoplasia and only 15 (14.40) for any type of neoplasia (Table IV). As for the NNE with colonoscopy to detect an invasive cancer the number is 30 (29.24), 3 (2.39) for significant neoplasia and 2 (1.44) for any type of neoplasia 
Table III. Positive predictive values obtained in the Colorectal Cancer Prevention Program in the region of Murcia between the years 2006 and 2010

Positive predictive value (PPV)

Total

PPV of high risk adenomas*

Number of persons with high risk adenomas/Number

of persons undergoing colonoscopy $\times 100$

PPV of low risk adenomas

Number of persons with low risk adenomas/Number

of persons undergoing colonoscopy $\times 100$

PPV of any adenoma

Number of persons with any adenoma/Number of

persons undergoing colonoscopy $x 100$

PPV of invasive cancer detected

66.02

Number of persons with invasive cancer detected/

Number of persons undergoing colonoscopy $x 100$

PPV of high risk adenomas and invasive cancer

detected

Number of persons with high risk adenomas and invasive

cancer detected/Number of persons undergoing

colonoscopy $\mathrm{x} 100$

PPV of any adenoma and invasive cancer detected

Number of persons with any adenoma and invasive

cancer detected/Number of persons undergoing

colonoscopy x 100

69.44

*Persons with 3 or more adenomas and/or some of them equal or greater than 10 $\mathrm{mm}$, or with a villous component or high grade dysplasia (includes the previously termed carcinoma in situ and intramucosal carcinoma).

(Table IV). Such results are conclusive regarding the effectiveness of these types of program based on FIT followed by colonoscopy for positive cases.

\section{THE THOUSAND MILLION EURO QUESTION: ARE THESE PROGRAMS WORTH SPENDING MONEY ON?}

A rigorous and as yet still unsurpassed study, published by its authors as part of a study carried out by the Ministry of Health, estimates the annual costs, both direct and indirect, of the most prevalent cancers in Spain, for 2003 (58). The results for CRC are shown in table V. The 870,565,133 euros of direct costs in 2003 become 1,096,041,502 euros in 2012,
Table IV. Number needed to screen (NNS) and number needed to examine (NNE) with colonoscopy obtained in the Colorectal Cancer Prevention Program in the region of Murcia between the years 2006 and 2010

\begin{tabular}{lll}
\hline Lesions & NNS* & NNE** \\
\hline High risk adenomas*** & $26(25.97)$ & $3(2.60)$ \\
Low risk adenomas & $37(36.36)$ & $4(3.64)$ \\
Any adenoma & $16(15.15)$ & $2(1.51)$ \\
Invasive cancer & $293(292.47)$ & $30(29.24)$ \\
High risk adenomas and invasive cancer & $24(23.85)$ & $3(2.39)$ \\
Any adenoma and invasive cancer & $15(14.40)$ & $2(1.44)$
\end{tabular}

*Number needed to screen to diagnose one case (Number of subjects with a valid test/number of subjects with the corresponding lesion). *Number needed to examine with colonoscopy to diagnose one case (Number of subjects undergoing colonoscopy / number of subjects with the corresponding lesion). ${ }^{* * *}$ Persons with 3 or more adenomas and / or some of them equal or greater than $10 \mathrm{~mm}$, or with a villous component or high grade dysplasia (includes the previously termed carcinoma in situ and intramucosal carcinoma).

updating income according to the Retail Price Index (RPI) (59) and using this same criterion the present costs are $1,232,459,951$ euros.

Taking again as an example the screening program in Murcia, the direct costs necessary to extend the program to the whole region of Murcia as far as diagnostic confirmation is concerned were for the year 2010 1,687,084 euros, divided into 994,445 for the estimated 4,942 colonoscopies and 692,639 euros for processing the 16,818 pathology samples. If we extrapolate the direct costs of CRC in Spain, previously presented in 2003 euros (870,565,133 euros) and convert them into 2010 euros, the figure obtained is $1,040,325,334$ euros. Given that, according to the national census Murcia represents $3.18 \%$ of the total national population (56) the direct costs for CRC that would correspond to Murcia in 2010 are 33,082,346 euros. In other words, the direct costs from the diagnostic confirmation stage of the CRC screening program in all the region represent just $5.1 \%$ of the total amount spent by the region on treating CRC. It would appear that such an amount could be acceptable given the effectiveness of the program and can even clearly be reduced by better management of the processes involved.

To conclude this section, a further extrapolation can be made. The population of Murcia between 50 and 69 years old $(270,999$ people) was in $20102.7 \%$ of the total number

Table V. Estimated costs for Spain, in 2003 euros, attributable to colorectal cancer (58)

\begin{tabular}{|c|c|c|c|c|}
\hline Concept & Costs & Accumulated & $\%$ of direct costs & $\%$ of total \\
\hline In-patient costs & $172,542,828$ & & 19.82 & 16.41 \\
\hline Out-patient costs & $482,930,448$ & $655,473,276$ & 55.4 & 45.94 \\
\hline Chemotherapy & $215,091,857$ & $870,565,133$ & 24.71 & 20.46 \\
\hline Indirect costs & $180,634,193$ & $1,051,199,326$ & & 17.18 \\
\hline Total & $1,051,199,326$ & & & 100.00 \\
\hline
\end{tabular}


of people with this age in Spain $(10,035,404$ people) (56). If the economic effort involved in full deployment of diagnostic confirmation for this $2.7 \%$ was $1,687,084$ euros, the corresponding figure for all of Spain would be 62,484,593 euros, which converted in 2012 euros would be 65,796,276 euros, just $6 \%$ of the total estimated direct cost of CRC in Spain.

With regard to the evaluation of costs and the potential savings to be obtained through screening, recently the Basque Country estimated all the costs attributable to its screening program and reached the conclusion that each cancer detected costs 7,324.4 euros, each advanced adenoma 941.8 euros and each person screened only 28.7 euros (60). Given that this program has diagnosed 3,874 people with high risk adenomas in the period 2009-2012, and estimating that $20 \%$ of these lesions will become malignant, the savings made by preventing the disease are $23,244,000$ euros (60). Furthermore, the average cost in the first year for the CRC detected at an advanced stage in this same region is 30,000 euros and so the early detection of the 543 patients diagnosed with cancer in this same program and time period represent a further saving of 12,303,068 euros (60). If both amounts are summed, the total is $35,547,068$ euros, for a period just over two years and without coverage extending to the whole population.

On $1^{\text {st }}$ April 2012 the population of the Basque Country was $4.6 \%$ of the national total (56). As the direct costs of CRC in Spain are estimated in 2012 to be $870,565,133$ euros (Table V), the part corresponding to the Basque Country would be 40,045,999 euros. Bearing in mind this figure and that estimated above of thirty five and a half million euros in savings that are produced in a program with wide coverage, but still below $60 \%$ of the population and approximately in a two-year period, it is reasonable to conclude that the savings obtained by a screening program is at least equivalent to $40 \%$ of the total direct costs caused by CRC in the territory covered by the program.

The international literature is replete with examples of economic assessments of screening programs. From the systematic review of this information (61-63) it can be concluded that the strategies based of FOBT are the most cost effective although this is also the case with sigmoidoscopy and colonoscopy but not so with CT colonography, fecal DNA or capsule endoscopy. This cost effectiveness is maintained even when adherence falls below $50 \%$ (64). The best analysis of cost effectiveness for CRC screening carried out in our country was published by López Bastida (65). In this study the most efficient strategy (the best cost / effectiveness relationship) was annual FIT. The incremental cost effectiveness ratio (ICER) for this annual test was 1,541 euros per quality-adjusted life year (QALY) gained. This ratio would even fall to 1,180 euros per QALY if the terminal costs are included in the model, which are those costs that would have been incurred if the screening had not been performed and that are avoided by early treatment. But the other screening strategies in the base analysis were very close when compared directly to the option of not screening.
Thus, that currently established by the National Cancer Strategy that is biannual FIT, offers the result of 2,265 euros per QALY gained.

Normally a process or procedure is considered cost effective if its ICER is lower than 30,000 euros, a condition which is amply met by FIT-based screening. As a comparison, these same authors estimate that the cost per QALY in the breast cancer screening program is 15,000 euros, a figure that is clearly higher than for CRC (66).

The fact that the costs of screening, although they are significant, are much lower than those for treating CRC with no early diagnosis, the fact that $\mathrm{CRC}$ avoided by the elimination of adenomas represents avoided CRC costs in the future and the fact that the spectacular cost effectiveness relationship allows no doubt as to the usefulness of these programs, do not mean that setting up such programs is an easy task for healthcare services. In spite of this, the net increase in colonoscopies that the screening programs burden healthcare facilities with must be accepted as an opportunity for optimization rather than as a threat. Optimization is based on three main elements: the planning of the necessary resources and healthcare circuits, the proper use of the indications for colonoscopy outside screening programs and the definition of evidence-based postpolypectomy follow-up protocols so that the population is not overexposed to unnecessary colonoscopies. Planning is one of the virtues that to date the Spanish screening programs possess and this planning has naturally had an influence on health services. It is crucial that this capacity for anticipation is maintained in the setting up and expansion of the remaining programs.

It is relatively easy to estimate the overuse of colonoscopies with the very high number of specimens for histologic analysis. Thus, as an example, in 2011 the Hospital Virgen de la Arrixaca in Murcia performed a total of 5,470 colonoscopies of which 891 (16.3\%) formed part of the screening program itself. This figure is interesting as it is below that which has been described for the indication of inadequate colonoscopies in a study carried out applying the new guidelines for appropriate use of endoscopy that was $18 \%$ (67). That is to say, it would be potentially possible to compensate the overuse of screening by eliminating the inappropriate indications for colonoscopy. The sustainability of programs must be achieved by appropriate use of the indications of endoscopic follow-up that the screening programs generate due to the very frequent polypectomies of adenomas that are performed in them. It is a fact that currently one of the major sources of inappropriate use of indications for colonoscopy is precisely this followup. The same authors of the study of appropriate use referred to above found that $46 \%$ of the colonoscopies indicated for post-polypectomy control were inappropriate, a further 19\% uncertain and only 35\% clearly appropriate (67). To avoid this dangerous spiral, it is crucial that screening programs assume the responsibility for post-polypectomy follow-up and that this is done in strict accordance with existing guidelines. 


\section{CONCLUSION}

Extending CRC screening programs is a mandate of NHS, it is a pertinent action, it is cost effective and will bring substantial savings in direct and indirect costs. It is true that its development will involve immediate expense but it is also true that opportunistic screening already entails high non-quantified costs and that the more slowly the population under screening control by the NHS is extended, the more this cost will increase. If work is carried out with the required rigor not only in the part related to the cancer Screening Program Network, which has already proven itself, but also in avoiding inappropriate use, the actual direct costs of the programs may be considerably lessened, thus optimizing even more their cost effectiveness. The prevention of CRC is justified especially in times of crisis as there is no better social cost invested than that which saves suffering, deaths and even money.

\section{REFERENCES}

1. Ferlay J, Shin HR, Bray F, Forman D, Mathers C and Parkin DM. GLOBOCAN 2008 v1.2, Cancer Incidence and Mortality Worldwide: IARC CancerBase No. 10 [Internet]. Lyon, France: International Agency for Research on Cancer; 2010. [Consultado 11/06/2012]. Disponible en: http://globocan.iarc.fr.

2. INE. INEBASE. 2012. Defunciones según la causa de muerte 2010. INE.es. [Consultado 11/06/2012]. Disponible en: http://www.ine.es/ $\mathrm{jaxi} /$ menu.do?type $=$ pcaxis $\&$ path $=/ \mathrm{t} 15 / \mathrm{p} 417 \&$ file $=$ inebase $\& \mathrm{~L}=0$.

3. World Health Organization. Cancer mortality database: CANCERMondial [Internet]. Lyon, France: International Agency for Research on Cancer; 2010. [Consultado 11/06/2012]. Disponible en: http://wwwdep.iarc.fr/WHOdb/WHOdb.htm.

4. Ribes J, Navarro M, Cleries R, Esteban L, Pareja L, Binefa G, et al. Colorectal cancer mortality in Spain: trends and projections for 19852019. Eur J Gastroenterol Hepatol 2009;21:92-100.

5. Cayuela A, Rodriguez-Dominguez S, Garzon-Benavides M, PizarroMoreno A, Giraldez-Gallego A, Cordero-Fernandez C. Study of colorectal mortality in the Andalusian population. Rev Esp Enferm Dig 2011:103:289-93.

6. Binefa Rodriguez G. Colorectal cancer mortality trends in Spain. What shall we do? Rev Esp Enferm Dig 2011;103:285-8.

7. Edwards BK, Ward E, Kohler BA, Eheman C, Zauber AG, Anderson RN, et al. Annual report to the nation on the status of cancer, 19752006, featuring colorectal cancer trends and impact of interventions (risk factors, screening, and treatment) to reduce future rates. Cancer 2010;116:544-73.

8. Winawer SJ, Zauber AG, Ho MN, O'Brien MJ, Gottlieb LS, Sternberg SS, et al. Prevention of colorectal cancer by colonoscopic polypectomy. The National Polyp Study Workgroup. N Engl J Med 1993;329:197781.

9. Brenner H, Bouvier AM, Foschi R, Hackl M, Larsen IK, Lemmens V, et al. Progress in colorectal cancer survival in Europe from the late 1980s to the early 21 st century: The EUROCARE study. Int J Cancer 2012;131:1649-58.

10. Jacob BJ, Moineddin R, Sutradhar R, Baxter NN, Urbach DR. Effect of colonoscopy on colorectal cancer incidence and mortality: an instrumental variable analysis. Gastrointest Endosc 2012;76:355-64 e1

11. Stock C, Knudsen AB, Lansdorp-Vogelaar I, Haug U, Brenner H. Colorectal cancer mortality prevented by use and attributable to nonuse of colonoscopy. Gastrointest Endosc 2011;73:435-43 e5.

12. Rabeneck L, Paszat LF, Saskin R, Stukel TA. Association between colonoscopy rates and colorectal cancer mortality. Am J Gastroenterol 2010;105:1627-32.

13. Zauber AG, Winawer SJ, O'Brien MJ, Lansdorp-Vogelaar I, van Ballegooijen M, Hankey BF, et al. Colonoscopic polypectomy and long- term prevention of colorectal-cancer deaths. N Engl J Med 2012; 366:687-96.

14. Baxter NN, Goldwasser MA, Paszat LF, Saskin R, Urbach DR, Rabeneck L. Association of colonoscopy and death from colorectal cancer. Ann Intern Med 2009;150:1-8.

15. Singh H, Nugent Z, Demers AA, Kliewer EV, Mahmud SM, Bernstein $\mathrm{CN}$. The reduction in colorectal cancer mortality after colonoscopy varies by site of the cancer. Gastroenterology 2010;139:1128-37.

16. Harewood GC, Lieberman DA. Colonoscopy practice patterns since introduction of medicare coverage for average-risk screening. Clin Gastroenterol Hepatol 2004;2:72-7.

17. Regula J, Rupinski M, Kraszewska E, Polkowski M, Pachlewski J, Orlowska J, et al. Colonoscopy in colorectal-cancer screening for detection of advanced neoplasia. N Engl J Med 2006;355:1863-72.

18. Kronborg O, Fenger C, Olsen J, Jorgensen OD, Sondergaard O. Randomised study of screening for colorectal cancer with faecal-occultblood test. Lancet 1996;348:1467-71.

19. Kewenter J, Brevinge H, Engaras B, Haglind E, Ahren C. Results of screening, rescreening, and follow-up in a prospective randomized study for detection of colorectal cancer by fecal occult blood testing. Results for 68,308 subjects. Scand J Gastroenterol 1994;29:468-73.

20. Mandel JS, Bond JH, Church TR, Snover DC, Bradley GM, Schuman LM, et al. Reducing mortality from colorectal cancer by screening for fecal occult blood. Minnesota Colon Cancer Control Study. N Engl J Med 1993:328:1365-71.

21. Hardcastle JD, Chamberlain JO, Robinson MH, Moss SM, Amar SS, Balfour TW, et al. Randomised controlled trial of faecal-occult-blood screening for colorectal cancer. Lancet 1996;348:1472-7.

22. Hewitson P, Glasziou P, Irwig L, Towler B, Watson E. Screening for colorectal cancer using the faecal occult blood test, Hemoccult. Cochrane Database Syst Rev 2007:CD001216.

23. Mandel JS, Church TR, Bond JH, Ederer F, Geisser MS, Mongin SJ, et al. The effect of fecal occult-blood screening on the incidence of colorectal cancer. N Engl J Med 2000;343:1603-7.

24. Faivre J, Dancourt V, Lejeune C, Tazi MA, Lamour J, Gerard D, et al. Reduction in colorectal cancer mortality by fecal occult blood screening in a French controlled study. Gastroenterology 2004;126:1674-80

25. Castiglione G, Sala P, Ciatto S, Grazzini G, Mazzotta A, Rossetti C, et al. Comparative analysis of results of guaiac and immunochemical tests for faecal occult blood in colorectal cancer screening in two oncological institutions. Eur J Cancer Prev 1994;3:399-405.

26. Parra-Blanco A, Gimeno-Garcia AZ, Quintero E, Nicolas D, Moreno SG, Jimenez A, et al. Diagnostic accuracy of immunochemical versus guaiac faecal occult blood tests for colorectal cancer screening. J Gastroenterol 2010;45:703-12.

27. van Rossum LG, van Rijn AF, Laheij RJ, van Oijen MG, Fockens P, van Krieken HH, et al. Random comparison of guaiac and immunochemical fecal occult blood tests for colorectal cancer in a screening population. Gastroenterology 2008;135:82-90.

28. Quintero E, Castells A, Bujanda L, Cubiella J, Salas D, Lanas A, et al. Colonoscopy versus fecal immunochemical testing in colorectal-cancer screening. N Engl J Med 2012;366:697-706.

29. Atkin WS, Edwards R, Kralj-Hans I, Wooldrage K, Hart AR, Northover $\mathrm{JM}$, et al. Once-only flexible sigmoidoscopy screening in prevention of colorectal cancer: a multicentre randomised controlled trial. Lancet 2010;375:1624-33.

30. Segnan N, Armaroli P, Bonelli L, Risio M, Sciallero S, Zappa M, et al. Once-only sigmoidoscopy in colorectal cancer screening: followup findings of the Italian Randomized Controlled Trial-SCORE. J Natl Cancer Inst 2011;103:1310-22.

31. Schoen RE, Pinsky PF, Weissfeld JL, Yokochi LA, Church T, Laiyemo $\mathrm{AO}$, et al. Colorectal-cancer incidence and mortality with screening flexible sigmoidoscopy. N Engl J Med 2012;366:2345-57.

32. Betes Ibanez M, Munoz-Navas MA, Duque JM, Angos R, Macias E, Subtil JC, et al. Diagnostic value of distal colonic polyps for prediction of advanced proximal neoplasia in an average-risk population undergoing screening colonoscopy. Gastrointest Endosc 2004;59:634-41.

33. Lakoff J, Paszat LF, Saskin R, Rabeneck L. Risk of developing proximal versus distal colorectal cancer after a negative colonoscopy: a population-based study. Clin Gastroenterol Hepatol 2008;6:1117-21.

34. Brenner H, Hoffmeister M, Arndt V, Stegmaier C, Altenhofen L, Haug $\mathrm{U}$. Protection from right- and left-sided colorectal neoplasms after colonoscopy: population-based study. J Natl Cancer Inst 2010;102:89-95. 
35. de Haan MC, van Gelder RE, Graser A, Bipat S, Stoker J. Diagnostic value of CT-colonography as compared to colonoscopy in an asymptomatic screening population: a meta-analysis. Eur Radiol 2011;21:1747-63.

36. Van Gossum A, Munoz-Navas M, Fernandez-Urien I, Carretero C, Gay G, Delvaux M, et al. Capsule endoscopy versus colonoscopy for the detection of polyps and cancer. N Engl J Med 2009;361:264-70.

37. Spada C, Hassan C, Munoz-Navas M, Neuhaus H, Deviere J, Fockens $\mathrm{P}$, et al. Second-generation colon capsule endoscopy compared with colonoscopy. Gastrointest Endosc 2011;74:581-9 e1.

38. Spada C, Hassan C, Galmiche JP, Neuhaus H, Dumonceau JM, Adler $\mathrm{S}$, et al. Colon capsule endoscopy: European Society of Gastrointestinal Endoscopy (ESGE) Guideline. Endoscopy 2012;44:527-36.

39. Ahlquist DA, Zou H, Domanico M, Mahoney DW, Yab TC, Taylor WR, et al. Next-generation stool DNA test accurately detects colorectal cancer and large adenomas. Gastroenterology 2012;142:248-56.

40. Estrategia en Cáncer del Sistema Nacional de Salud. Actualización aprobada por el Consejo Interterritorial del Sistema Nacional de Salud, el 29 de octubre de 2009. Ministerio de Sanidad y Política Social, 2010.

41. Segna N, Patrick J, von Karsa L, editors. European Commission. European Guidelines for Quality Assurance in Colorectal Cancer Screening and Diagnosis. 1st ed. Luxembourg: Publications Office of the European Union; 2010. p. LX 386.

42. Red de programas de cribado de cáncer. 2012. [Consultado 11/06/2012]. Disponible en: http://www.cribadocancer.com/.

43. Pérez-Riquelme F, Peris M, Sala L, Ascunde N, De las Heras M, Cruzado J, et al. Recomendaciones del panel de expertos para planificación y puesta en marcha de programas organizados de base demográfica para la prevención del cáncer de colon y recto. Murcia: Consejería de Sanidad de la Región de Murcia: 2008. Serie Informes No: 49.48 pp.

44. Muñoz Navas M, Pampliega T, Zozaya J, Lucas I, Conchillo F. Utilidad de la sigmoidoscopia dentro del examen médico de salud. Resultados preliminares. XXIX Reunión Nacional Extraordinaria de la Sociedad Española de Patología Digestiva. Santander, 20-22 de junio de 1985.

45. Muñoz Navas M, Angós R, Val J, García L, Jiménez FJ, Zozaya JM. Total colonoscopy in the screening for colorectal cancer in asymptomatic patients. Gastroenterology 1991;100:A388.

46. Cortés F, Artal F, Garcés A, Izcara J, Lacasa E, Zubiri F. Cáncer colorrectal: detección mediante la prueba del guayaco en un centro de atención primaria. Med Clin (Barc) 1992;98:325-8.

47. García A, Carballo F, de la Morena J. Aplicabilidad de programas de screening para cáncer colorrectal basados en el test de hemorragias ocultas en heces. Rev ACAD 1993;IX:40-1.

48. Tárraga PJ, Marín E, Celada A, García-Molinero MJ, García-Olmo D, Solera J. Evaluación económica del cáncer colorrectal mediante detección de sangre oculta en heces. Rev Esp Enferm Dig 2000; 92:334-41.

49. Betes M, Munoz-Navas MA, Duque JM, Angos R, Macias E, Subtil $\mathrm{JC}$, et al. Use of colonoscopy as a primary screening test for colorectal cancer in average risk people. Am J Gastroenterol 2003;98:2648-54.

50. Castells A, Andreu M. Proyecto EPICOLON: una contribución al conocimiento del síndrome de Lynch y otras formas hereditarias o familiares de cáncer colorrectal. Med Clin (Barc) 2007;128:55-60.

51. Grupo de trabajo de la guía de práctica clínica de prevención del cáncer colorrectal. Actualización 2009. Guía de práctica clínica. Barcelona: Asociación Española de Gastroenterología, Sociedad Española de Medicina de Familia y Comunitaria, y Centro Cochrane Iberoamericano; 2009. Programa de Elaboración de Guías de Práctica Clínica en Enfer- medades Digestivas, desde la Atención Primaria a la Especializada: 4. Disponible en: http://www.guiasgastro.net/guias_full/textos/ccolon.pdf. 52. Castells A, Marzo-Castillejo M, Mascort JJ, Amador FJ, Andreu M, Bellas B, et al. Guía de práctica clínica. Prevención del cáncer colorrectal. Actualizacion 2009. Gastroenterol Hepatol 2009;32:717 e1-58.

53. Jover R, editor. Guía de práctica clínica de calidad en la colonoscopia de cribado del cáncer colorrectal. Madrid: EDIMSA; 2011. Disponible en: http://www.aegastro.es/docs/cribado_colon.pdf.

54. Jover R, Herraiz M, Alarcon O, Brullet E, Bujanda L, Bustamante M, et al. Clinical practice guidelines: quality of colonoscopy in colorectal cancer screening. Endoscopy 2012;44:444-51.

55. Morillas JD, Castells A, Oriol I, Pastor A, Perez-Segura P, Echevarria JM, et al. Alianza para la Prevención del Cáncer de Colon en España: un compromiso cívico con la sociedad. Gastroenterol Hepatol 2012; 35:109-28.

56. INE. INEbase 2012. Demografía y población. Cifras de población y Censos demográficos. INE.es. [Consultado 11/06/2012]. Disponible en: http://www.ine.es/inebmenu/mnu_cifraspob.htm.

57. Salas D. Situación actual de los programas de cribado de cáncer colorrectal en España. XV Reunión Anual de la Red de Programas de Cribado de Cáncer. Pamplona, 20-22 de junio de 2012. [Consultado 19/09/2012]. Disponible en: http://www.programascancerdemama.org/ index.php/ reunion-anual-red-programas-de-cribado-cancer-pamplona-2012

58. Antoñanzas F, Oliva J, Velasco M, Zosaya N, Lorente R, Lopez-Bastida J. Costes directos e indirectos del cáncer en España. Cuadernos económicos de ICE; 2006:281-309.

59. INE. INEBASE. 2012. INEbase / Indice de Precios de Consumo (Base 2011) / ¿Quiere actualizar una renta? INE.es. [Consultado 16/06/2012]. Disponible en: http://www.ine.es/calcula/.

60. Pérez Gil J. Comunicado en Conferencia-Debate Prevenir o Curar en Época de Crisis. Semana Enfermedades Digestivas, Bilbao 5 de junio, 2012.

61. Lansdorp-Vogelaar I, Knudsen AB, Brenner H. Cost-effectiveness of colorectal cancer screening - an overview. Best Pract Res Clin Gastroenterol 2010;24:439-49.

62. Cruzado J, Carballo F, Pérez-Riquelme F. Evaluación económica de los cribados de cáncer de colon y recto: una revisión sistemática. Rev Esp Enferm Dig 2011;103(Supl.I):178.

63. Lansdorp-Vogelaar I, Knudsen AB, Brenner H. Cost-effectiveness of colorectal cancer screening. Epidemiol Rev 2011;33:88-100.

64. Maciosek MV, Solberg LI, Coffield AB, Edwards NM, Goodman MJ. Colorectal cancer screening: health impact and cost effectiveness. Am J Prev Med 2006;31:80-9.

65. López Bastida J. Análisis coste-efectividad del cribado del cáncer colorrectal en la población general. Santa Cruz de Tenerife: Servicio Canario de la Salud, D.L. 2010. 90 p. (Colección: Informes, estudios e investigación. Ministerio de Sanidad y Consumo. Serie: Informes de Evaluación de Tecnologías Sanitarias. SESCS; 2006/23). Disponible en: http://www2.gobiernodecanarias.org/sanidad/scs/content/5b3b85621f35-11e0-964e-f5f3323ccc4d/2006_23.pdf.

66. López-Bastida J. Análisis coste-efectividad del cribado del cáncer colorrectal en España. En: Cribado del cáncer de colon en España ¿es costeeficaz? Alianza para la Prevención del Cáncer de Colon en España. Madrid, 2011. Disponible en: https://www.aecc.es/Comunicacion/publicaciones/Documents/Informe\%20Coste\%20Efectividad.pdf.

67. Carrion S, Marin I, Lorenzo-Zuniga V, Moreno De Vega V, Boix J. Adecuación de la indicación de la colonoscopia según los nuevos criterios de EPAGE II. Gastroenterol Hepatol 2010;33:484-9. 